\title{
Árangur kransæðahjáveituaðgerða hjá konum á Íslandi
}

\author{
Helga Rún Garðarsdóttir ${ }^{1}$ kandídat \\ Linda Ósk Árnadóttir ${ }^{1}$ deildarlæknir \\ Jónas A. Aðalsteinsson ${ }^{1}$ deildarlæknir \\ Hera Jóhannesdóttir ${ }^{1}$ deildarlæknir \\ Sólveig Helgadóttir ${ }^{4}$ leknir \\ Pórdís Jóna Hrafnkelsdóttir ${ }^{2,3}$ æknir \\ Arnar Geirsson ${ }^{5}$ læknir \\ Tómas Guðbjartsson ${ }^{1,3}$ |æknir
}

${ }^{1}$ Hjarta- og lungnaskurðdeild, ${ }^{2}$ hjartadeild Landspítala, ${ }^{3} æ$ æknadeild Háskóla Íslands, ${ }^{4}$ svæfinga- og gjörgæsludeild Akademíska sjúkrahússins í Uppsölum, Svípjóð, ${ }^{5}$ hjartaskurðdeild Yale New Haven spítala, Bandaríkjunum.

Fyrirspurnum svarar Tómas Guðbjartsson, tomasgud@landspitali.is

\section{Inngangur}

Kransæðasjúkdómur er ein helsta dánarorsök Íslendinga, bæði kvenna og karla. ${ }^{1}$ Fyrir tíðahvörf er tíðni kransæðasjúkdóms lægri meðal kvenna og pær eru að jafnaði allt að áratug eldri en karlar pegar pær greinast með sjúkdóminn. ${ }^{2}$ Ástæðan fyrir pessum mun er ekki að öllu leyti pekkt en er helst rakin til verndandi áhrifa estrógens sem hefur æðavíkkandi áhrif og hamlar framrás æðakölkunar. ${ }^{3}$ Aftur á móti getur töf á greiningu einnig átt sinn pátt par sem einkenni kransæðasjúkdóms hjá konum eru oft frábrugðin peim sem lýst hefur verið hjá karlmönnum. ${ }^{4}$

Helstu meðferðarúrræði kransæðasjúkdóms eru lífsstílsbreytingar og lyfjameðferð en við alvarlegri tilfelli parf að beita inngripum, svo sem kransæðavíkkun eða jafnvel kransæðahjáveituaðgerð. Helsta ábending fyrir kransæðahjáveitu er sjúkdómur sem nær til allra meginkransæða hjartans, sérstaklega ef prengsli eru í vinstri höfuðstofni eða ofarlega í framveggsgrein hjartans (left anterior descending artery, LAD). Alpjóðlegar leiðbeiningar gera lítinn greinamun á meðferð kransæðasjúkdóms hjá konum og körlum. ${ }^{5,6}$ Nýleg sænsk rannsókn sýndi pó að konur hlutu síður meðferð samkvæmt klínískum leiðbeiningum, bæði hvað varðar lyfjameðferð og inngrip.?

Engin íslensk rannsókn hefur borið saman meðferð kransæðasjúkdóms með hjáveituaðgerð milli kynja. Pótt konur séu yfirleitt um fjórðungur pessara sjúklinga hefur árangur aðgerðarinnar hjá konum lítið verið rannsakaður. Í erlendum rannsóknum eru konur yfirleitt nokkrum árum eldri en karlar pegar pær gangast undir kransæðahjáveitu og með fleiri áhættupætti kransæðasjúkdóms. ${ }^{8-12}$ Dánartíðni innan 30 daga frá kransæðahjáveitu hefur lækkað töluvert á síðustu áratugum en er pó hærri hjá konum, eða á bilinu 1,5-6\% borin saman við 1-3\% hjá körlum. ${ }^{8-14}$ Pessi munur endurspeglast í EuroSCORE áhættulíkaninu sem metur dánarlík-

\begin{abstract}
Á G R I P
Inngangur

Markmið pessarar rannsóknar var að bera saman árangur kransæðahjáveituaðgerða hjá konum og körlum á Íslandi með áherslu á snemmog síðkomna fylgikvilla, 30 daga dánartíðni og langtímalifun.

\section{Efniviður og aðferðir}

Afturskyggn rannsókn á öllum sjúklingum sem gengust undir kransæðahjáveituađgerð á Íslandi á árunum 2001-2013. Upplýsingar fengust úr sjúkraskrám og Dánarmeinaskrá Embættis landlæknis. Fylgikvillum var skipt í snemm- og síðkomna fylgikvilla og heildarlifun reiknuð með aðferð Kaplan-Meier. Fjölpátta aðhvarfsgreining var notuð̃ til að̛ meta forspárpætti dauð̃a innan 30 daga og Cox aðhvarfsgreining til að meta forspárpætti verri langtímalifunar. Meðaleftirfylgd var 6,8 ár.
\end{abstract}

\section{Niðurstöður}

Af 1755 sjúklingum voru 318 konur (18\%). Meðalaldur peirra var fjórum árum hærri en karla (69 ár á móti 65 árum, $p<0,001)$, pær höfðu oftar sögu um háprýsting ( $72 \%$ á móti $64 \%, p=0,009)$ og EuroSCOREst peirra var hærra (6,1 á móti 4,3, p<0,001). Hlutfall annarra áhættupátta eins og sykursýki var hins vegar sambærilegt, líkt og útbreiðsla kransæðasjúkdóms. Alls létust 12 konur (4\%) og 30 karlar (2\%) innan 30 daga frá aðgerð en munurinn var ekki marktækur $(p=0,08)$. Tíðni snemmkominna fylgikvilla, bæði minniháttar ( $53 \%$ á móti $48 \% \mathrm{p}=0,07$ ) og alvarlegra (13\% á móti $11 \%, p=0,2)$, var sambærileg. Fimm árum frá aðgerð̃ var lifun kvenna $87 \%$ borin saman við $90 \%$ hjá körlum $(p=0,09)$. Pá var tíðni síðkominna fylgikvilla sambærileg hjá konum og körlum 5 árum frá ađgerð (21\% á móti 19\%, p=0,3). Kvenkyn reyndist hvorki sjálfstæđur forspárpáttur 30 daga dánartíđni (OR 0,99; 95\%ÖB: 0,97-1,01) né verri lifunar (HR 1,08; 95\%-ÖB: 0,82-1,42).

\section{Ályktun}

Mun færri konur en karlar gangast undir kransæðahjáveituaðgerð á Íslandi og eru pær fjórum árum eldri pegar kemur að aðgerð. Árangur kransæðahjáveitu er góður hjá konum líkt og körlum, en 5 árum eftir aðgerð eru $87 \%$ kvenna á lífi.

doi.org/10.17992//bl.2018.0708.192

ur innan 30 daga frá opinni hjartaaðgerð en par er kvenkyn sérstakur áhættupáttur..$^{15}$ Pær fáu rannsóknir sem hafa borið saman langtímalifun milli kynja eftir kransæðahjáveitu hafa í flestum tilvikum sýnt lakari horfur kvenna. ${ }^{8,16,17}$ Rannsóknum virðist pó ekki bera saman um hvort kvenkyn sé sjálfstæður áhættupáttur síðri lifunar eftir kransæðahjáveitu, enda pótt nýleg safngreining á 20 rannsóknum hafi bent til pess. ${ }^{16}$

Árangur kransæðahjáveituaðgerða á Íslandi hefur töluvert verið rannsakaður á síðustu árum og hafa vísindagreinar verið birtar úr pessum efnivið. Meðal annars hafa undirhópar sjúklinga, eins og aldraðir, sykursjúkir og sjúklingar sem pjást af offitu, verið teknir fyrir en einnig birtist nýlega rannsókn um langtímaárangur eftir kransæðahjáveitu. ${ }^{18-21}$ 
Markmið pessarar rannsóknar var að bera saman árangur kransæðahjáveituaðgerða hjá konum og körlum á Íslandi með áherslu á dánartíðni innan 30 daga, fylgikvilla og lifun.

\section{Efniviður og aðferðir}

Rannsóknin var afturskyggn og náði til allra sjúklinga sem gengust undir kransæðahjáveituaðgerð á Landspítala á tímabilinu 1. janúar 2001 til 31. desember 2013. Peir sjúklingar sem gengust undir aðra hjartaaðgerð samhliða kransæðahjáveitu voru útilokaðir. Sjúklingar voru fundnir með leit í tveimur miðlægum skrám; annars vegar í aðgerðaskrá hjarta- og lungnaskurðdeildar Landspítala og hins vegar í sjúklingabókhaldi Landspítala. Í síðarnefndu skránni var leitað eftir aðgerðarnúmerum fyrir kransæðahjáveituaðgerðir (FNSA00, FNSC10, FNSC20, FNSC30) og fyrir aðgerðir par sem notast var við hjarta- og lungnavél (HLV) (FZSA00, FZSA10).

Klínískar upplýsingar um sjúklinga fengust úr sjúkraskrám, aðgerðarlýsingum og svæfingarskýrslum. Skráðar voru upplýsingar um kyn, aldur og líkamspyngdarstuðul. Einnig voru eftirtaldir áhættupættir hjarta- og æðasjúkdóma skráđir: háprýstingur, sykursýki, blóðfituröskun og reykingar. Ættarsaga var ekki tekin með vegna ófullnægjandi skráningar. Einkenni hjartabilunar voru metin samkvæmt flokkun New York Heart Association (NYHA), ${ }^{22}$ en einkenni um hjartaöng með flokkun Canadian Cardiovascular Society (CCS). ${ }^{23}$ Staðlað EuroSCOREst (European System for Cardiac Operative Risk Evaluation) var reiknað fyrir alla sjúklingana og pannig lagt mat á líkur á dauða innan 30 daga frá aðgerð. ${ }^{15}$ Skráð var fyrri saga um hjarta- og æðasjúkdóma en til peirra töldust hjartadrep, hjartabilun, gáttatif og önnur saga um hjartsláttaróreglu, en einnig saga um lokusjúkdóma eða kransæðavíkkun. Kreatínin var mælt fyrir aðgerð og útreiknaður gaukulsíunarhraði (GSH) metinn eftir pví. Nýrnastarfsemi var flokkuð samkvæmt Kidney Disease Outcome Quality Initiative, ${ }^{24}$ og var langvinn nýrnabilun skilgreind sem GSH $<60 \mathrm{ml} / \mathrm{mín} / 1,73 \mathrm{~m}^{2}$ (flokkar 3-5).

Útbreiðsla kransæðasjúkdómsins var metin samkvæmt svörum úr kransæðamyndatöku og var sérstaklega skráð ef um priggja æða kransæðasjúkdóm eða vinstri höfuðstofnsprengsli væri að ræða. Útstreymisbrot vinstri slegils var skráð samkvæmt niðurstöðum hjartaómunar fyrir aðgerð og var hjartabilun skilgreind sem útstreymisbrot vinstri slegils $<30 \%$.

Skráð var hvort um neyðaraðgerð hafi verið að ræða en hún var skilgreind sem aðgerð sem gerð var innan 24 klukkustunda frá innlögn. Einnig var athugað hvort aðgerðin var framkvæmd á sláandi hjarta eða með aðstoð hjarta- og lungnavélar. Aðgerðartími var skráđur í mínútum. Fjöldi æðatenginga á kransæðar (distal anastomoses) var skráður og hvort vinstri innri brjóstholsslagæð (left internal mammary artery, LIMA) hafði verið notuð sem æðagræðlingur. Blæðing í brjóstholskera fyrstu 24 klukkustundum eftir aðgerð var skráð í millilítrum $(\mathrm{mL})$ og einnig var skráður fjöldi eininga rauðkornapykknis sem sjúklingi voru gefnar í aðgerðinni eða í fyrstu vikunni eftir aðgerð. Legutími á gjörgæslu sem og heildarlegutími var talinn í dögum eftir aðgerð.

Fylgikvillum var skipt í snemmkomna, ef peir greindust innan 30 daga frá aðgerð, og síðkomna fylgikvilla ef peir greindust síðar. Snemmkomnir fylgikvillar voru flokkaðir í minniháttar eða alvar-
Tafla I. Aldur og tíðni helstu áhættupátta. Fjöldi (\%) eða meðaltöl með staðalfráviki.

\begin{tabular}{lccc}
\hline & Konur & Karlar & p-gildi \\
\hline Fjöldi & $318(18)$ & $1437(82)$ & \\
\hline Aldur, ár & $68,6 \pm 9,1$ & $65,4 \pm 9,3$ & $<0,001$ \\
\hline Áhættupættir hjarta- og æðasjúkdóma & & \\
\hline - Háprýstingur & $227(72)$ & $914(64)$ & 0,009 \\
\hline - Sykursýki & $53(17)$ & $227(16)$ & 0,8 \\
\hline - Blóðfituröskun & $180(59)$ & $811(58)$ & 1 \\
\hline - Saga um reykingar & $199(64)$ & $1021(73)$ & 0,002 \\
\hline Líkamspyngdarstuðull (kg/m²) & $28,1 \pm 5,6$ & $28,2 \pm 4,2$ & 0,8 \\
\hline EuroScOREst & $6,1 \pm 3,1$ & $4,3 \pm 3,2$ & $<0,001$ \\
\hline Prengsli í vinstri höfuðstofni & $138(43)$ & $583(41)$ & 0,4 \\
\hline Saga um kransæðavíkkun & $53(17)$ & $316(22)$ & 0,04 \\
\hline
\end{tabular}

lega fylgikvilla. Gáttatif/gáttaflökt, aftöppun fleiðruvökva, yfirborðssýking í skurðsári, lungnabólga, pvagfærasýking og skammvinn heilablóðpurrð voru talin til minniháttar fylgikvilla. Til alvarlegra fylgikvilla töldust blóðpurrð í hjarta, heilablóðfall, fjöllíffærabilun, bringubeinslos, djúp sýking og bráður nýrnaskaði. Blóðpurrð í hjartavöðva var skilgreind sem nýtilkomnar ST-hækkanir eða nýtilkomið vinstra greinrof á hjartalínuriti ásamt hækkun á CKMB (creatine kinase-MB) yfir 70 ng/L. Bráður nýrnaskaði var metinn með RIFLE-flokkun og var skilgreindur sem preföld aukning á kreatínín-gildi eða 75\% skerðing á gaukulsíunarhraða sem er RIFLE-flokkur F. ${ }^{25}$ Loks var skráð ef sjúklingur lést innan 30 daga frá aðgerð.

Allar komur á heilbrigðisstofnanir landsins eftir útskrift voru skoðaðar í leit að meiriháttar síðkomnum fylgikvillum sem tengdust hjarta- og æðakerfi en peir voru hjartaáfall, heilablóðfall, endurkransæðavíkkun, endurhjáveituaðgerð og dauði. Allir pessir fylgikvillar voru síðan teknir saman í einn endapunkt sem kallast MACCE (major adverse cardiac and cerebrovascular event).

Upplýsingar um dánardag fengust úr Dánarmeinaskrá Embættis landlæknis og miðaðist eftirfylgd við 1. júlí 2014. Meðaleftirfylgdartími var 6,8 ár (bil: 0,1-13,4 ár).

\section{Tölfræði}

Upplýsingar voru skráđar í tölvuforritið Excel. Tölfræðiúrvinnsla var gerð í tölfræðiforritinu $R$, útgáfu 3.0.3 ( $R$ foundation for Statistical Computing, Vín, Austurríki). Talnabreytur voru bornar saman með t-prófi en flokkabreytur með kí-kvaðrat eða Fischerexact prófi. Marktæki miðaðist við p-gildi <0,05. Notuð var Poisson-aðhvarfsgreining til að meta áhættu á snemmkomnum fylgikvillum hjá konum miðað við karla. Aðferð Kaplan-Meier var notuð til að reikna heildarlifun og lifun án MACCE. Lógistísk aðhvarfsgreining (logistic regression) var notuð til að meta forspárpætti dauða innan 30 daga. Voru peir gefnir upp sem gagnlíkindahlutfall (odds ratio, OR) með 95\% öryggisbilum (confidence interval, CI). Forspárpættir lifunar voru metnir með aðhvarfsgreiningu Cox (Cox regression analysis) og reiknað áhættuhlutfall (hazard ratio, HR) með 95\% öryggisbilum. Inn í líkönin voru settar pær breytur 
Tafla II. Aðgerðartengdir pættir og dvalartími á sjúkrahúsi. Fjöldi (\%) eða međaltöl með staðalfráviki.

\begin{tabular}{lccc}
\hline & Konur & Karlar & p-gildi \\
\hline Neyðaraðgerð & $20(6)$ & $63(4)$ & 0,2 \\
\hline Aðgerð á sláandi hjarta & $78(25)$ & $302(21)$ & 0,2 \\
\hline - aðgerð breytt yfir á HLV* & $13(17)$ & $27(9)$ & 0,03 \\
\hline LIMA-græðlingur notaður & $291(92)$ & $1362(95)$ & 0,04 \\
\hline Fjöldi fjærtenginga & $3,3 \pm 0,9$ & $3,5 \pm 0,9$ & $<0,001$ \\
\hline Aðgerðartími, mín & $217 \pm 56$ & $211 \pm 60$ & 0,1 \\
\hline Blæðing fyrstu 24 klst. mL & $873 \pm 645$ & $984 \pm 687$ & 0,006 \\
\hline Fjöldi ein. af rauðkornapykkni & $1,6 \pm 2,1$ & $2,8 \pm 2,0$ & $<0,001$ \\
\hline Legutími á gjörgæslu, dagar & $1,9 \pm 3,2$ & $2,0 \pm 2,9$ & 0,4 \\
\hline Heildarlegutími, dagar & $12,2 \pm 8,1$ & $10,7 \pm 7,6$ & 0,003 \\
\hline * hjarta- og lungnavél & & &
\end{tabular}

sem höfðu p-gildi undir 0,1 í einbreytugreiningu eða eru pekktar úr öðrum sambærilegum rannsóknum sem forspárpættir. Allar breyturnar stóðust kröfur um hlutfallsbil (proportionality).

Áður en rannsóknin hófst voru fengin öll tilskilin leyfi frá Persónuvernd og sampykki frá vísindasiðanefnd.

\section{Niðurstöður}

Alls gengust 1755 sjúklingar undir kransæðahjáveituaðgerð á tímabilinu og voru konur 318 (18\%) en karlar 1437 (82\%).

Áhættupættir kransæðasjúkdóms, útbreiðsla og aldur

Í töflu I sést samanburður milli kynja á helstu áhættupáttum hjarta- og æðasjúkdóma. Meðalaldur kvenna var fjórum árum hærri en karla, pær höfðu marktækt oftar sögu um háprýsting (72\% á móti 64\%, p=0,009) og EuroSCOREst peirra var hærra $(6,1$ á móti 4,3, p<0,001). Karlmenn höfðu oftar sögu um reykingar en hlutfall annarra áhættupátta, eins og sykursýki og blóðfituröskunar, var hins vegar sambærilegt. Útbreiðsla kransæðasjúkdóms, par með talið hlutfall priggja æða sjúkdóms og vinstri höfuðstofnsprengsla, var sambærileg milli kynja sem og útstreymisbrot vinstri slegils sem var að meðaltali í kringum 55\%.

\section{Einkenni og fyrri hjartasaga}

Konur höfðu marktækt alvarlegri hjartaöng skv. flokkun CCS (82\% á móti $73 \%$ í flokkum III og IV, p=0,02) og oftar einkenni hjartabilunar samkvæmt flokkun NYHA (61\% á móti 53\% í flokkum III og IV, p=0,02) en karlar. Par að auki voru konur oftar með skerta nýrnastarfsemi fyrir aðgerð, eða í 29\% tilfella borið saman við $13 \%(\mathrm{p}<0,001)$ karla. Fyrri saga um hjarta- og æðasjúkdóma eins og hjartadrep, hjartabilun og gáttatif var sambærileg milli kynja en færri konur en karlar höfðu farið í kransæðavíkkun (17\% á móti $22 \%, p=0,04)$.

\section{Aðgerðartengdir pættir}

Pættir tengdir aðgerðinni eru sýndir í töflu II. Tíðni neyðaraðgerða var sambærileg fyrir bæði kyn, eða í kringum 5\%. Hlutfall sjúklinga sem gekkst undir aðgerð á sláandi hjarta var einnig svipað fyrir bæði kyn, eða 26\% hjá konum og 23\% hjá körlum ( $\mathrm{p}=0,2)$. Hjá konum var hins vegar marktækt fleiri aðgerðum á sláandi hjarta breytt yfir í aðgerð með hjarta- og lungnavél, eða 17\% á móti 9\% aðgerða hjá körlum ( $\mathrm{p}=0,03)$.

\section{Snemmkomnir fylgikvillar og 30 daga dánartíðni}

Í töflu III sjást snemmkomnir fylgikvillar eftir aðgerð hjá báðum kynjum. Tíðni minniháttar fylgikvilla var að mestu sambærileg milli kynja. Konur greindust pó oftar með pvagfærasýkingu og hjá peim varð oftar að tappa af fleiðruvökva en hjá körlum. Tíðni alvarlegra fylgikvilla var sambærileg milli kynja. Alls létust 12 konur (4\%) og 30 karlar (2\%) innan 30 daga en munurinn var ekki marktækur $(\mathrm{p}=0,1)$. Ef teknar voru valaðgerðir eingöngu var 30

Tafla III. Snemmkomnir fylgikvillar kransæðahjáveitu. Fjöldi (\%) og gagnlíkindahlutfall með 95\% öryggisbili.

\begin{tabular}{|c|c|c|c|c|}
\hline & Konur & Karlar & Gagnlíkindahlutfall (95\%-ÖB) & p-gildi \\
\hline Allir minniháttar fylgikvillar & $169(53)$ & $686(48)$ & $1,1(0,9-1,3)$ & 0,2 \\
\hline - Gáttatif & $111(35)$ & $468(33)$ & $1,1(0,9-1,3)$ & 0,4 \\
\hline - Aftöppun fleiðruvökva & $50(16)$ & $147(10)$ & $1,5(1,1-2,5)$ & 0,008 \\
\hline - Lungnabólga & $22(7)$ & $93(6)$ & $1,1(0,7-1,7)$ & 0,8 \\
\hline - Pvagfærasýking & $29(10)$ & $33(2)$ & $4,0(2,4-6,6)$ & $<0,001$ \\
\hline - Yfirborðssýking í skurðsári & $39(12)$ & $144(10)$ & $1,2(0,9-1,7)$ & 0,3 \\
\hline - Skammvinn heilablóðpurrð & $5(2)$ & $16(1)$ & $1,4(0,5-3,6)$ & 0,5 \\
\hline Allir alvarlegir fylgikvillar & $41(13)$ & $147(11)$ & $1,3(0,9-1,8)$ & 0,2 \\
\hline - Miðmætisbólga & $3(1)$ & $13(1)$ & $1,0(0,2-3,2)$ & 1,0 \\
\hline - Hjartadrep & $38(12)$ & $134(10)$ & $1,3(0,9-1,8)$ & 0,2 \\
\hline - Heilablóðfall & $2(0,6)$ & $7(0,5)$ & $1,3(0,2-5,4)$ & 0,4 \\
\hline - Bringubeinslos & $5(2)$ & $22(2)$ & $1,0(0,3-2,5)$ & 0,9 \\
\hline - Fjöllíffærabilun & $13(4)$ & $42(3)$ & $1,4(0,7-2,5)$ & 0,3 \\
\hline - Bráđur nýrnaskaði (RIFLE F) & $4(1)$ & $9(0,6)$ & $2,0(0,5-6,2)$ & 0,2 \\
\hline Dánarhlutfall innan 30 daga & $12(4)$ & $30(2)$ & $1,8(0,9-3,4)$ & 0,08 \\
\hline
\end{tabular}




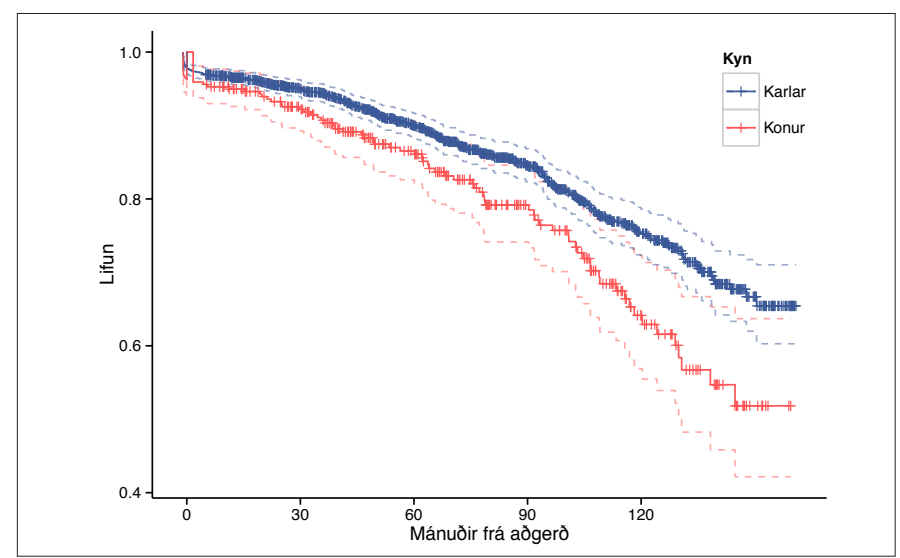

Mynd 1a. Kaplan-Meier-graf sem sýnir lifun kvenna og karla sem gengust undir kransæðahjáveituaðgerð á Íslandi frá 2001-2013 og 95\% öryggisbil (brotalínur).

daga dánartíðni kvenna 1,3\% samanborið við 1,4\% hjá körlum $(p=1)$. Heldur fleiri konur gengust undir neyðaraðgerð, eða 6\% borið saman við 4\% karla. Dánartíðni peirra kvenna innan 30 daga frá aðgerð var 30\% borið saman við 19\% hjá körlum en munurinn var ekki marktækur $(\mathrm{p}=0,3)$.

Í töflu IVa eru sýndir forspárpættir dauða innan 30 daga frá aðgerð en helstu sjálfstæðu áhættupættirnir fyrir dauða voru langvinn nýrnabilun, hjartabilun og hærri aldur. Kvenkyn reyndist hins vegar ekki sjálfstæður forspárpáttur dauða innan 30 daga (OR 1,00; 95\%-ÖB: 0,98-1,01, p=0,5)

\section{Lifun}

Mynd 1a sýnir heildarlifun sjúklinga eftir aðgerð. Einu ári eftir aðgerð voru 95\% (95\%-ÖB: 93-98) kvenna á lífi borið saman við 97\% (95\%-ÖB: 96-98) karla og var munurinn ekki marktækur $(\mathrm{p}=0,2)$. Ekki reyndist heldur marktækur munur á lifun 5 árum eftir aðgerð, eða 87\% (95\%-ÖB: 83-91) hjá konum borið saman við 90\% (95\%-ÖB: 89-92) hjá körlum ( $\mathrm{p}=0,2)$.

\section{Síðkomnir fylgikvillar}

Á mynd $1 \mathrm{~b}$ sést tíðni MACCE en einu ári eftir aðgerð var hún $8 \%$ hjá báðum kynjum $(\mathrm{p}=0,2)$. Fimm árum eftir aðgerð var tíðni MACCE ívið hærri hjá konum, eða 21\% borið saman við 19\% hjá körlum, án pess pó að munurinn væri marktækur $(p=0,3)$. Ein kona (0,3\%) og 7 karlmenn (0,4\%) purftu á endurhjáveituaðgerð að halda

Tafla IVa. Sjálfstæðir forspárpættir dauða innan 30 daga frá kransæðahjáveitu. Gagnlíkindahlutfall og 95\% öryggisbil.

\begin{tabular}{lccc}
\hline Forspárpáttur & Gagnlíkindahlutfall & $95 \%$ ÖB & p-gildi \\
\hline Aldur, ár & 1,00 & $1,00-1,00$ & $<0,001$ \\
\hline Kvenkyn & 1,00 & $0,98-1,01$ & 0,6 \\
\hline Háprýstingur & 0,99 & $0,98-1,01$ & 0,4 \\
\hline Sykursýki & 1,01 & $0,99-1,03$ & 0,1 \\
\hline Langvinn nýrnabilun & 1,04 & $1,02-1,13$ & $<0,001$ \\
\hline Hjartabilun & 1,07 & $1,03-1,13$ & 0,03 \\
\hline
\end{tabular}

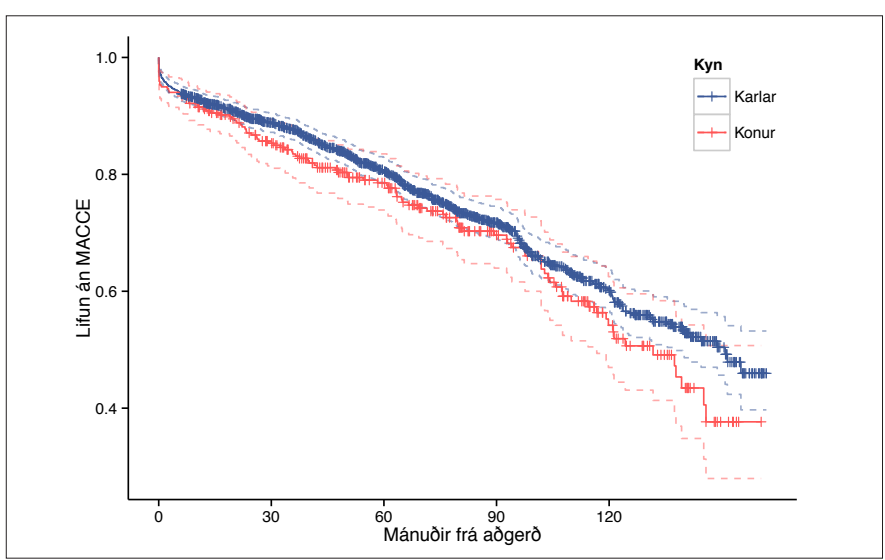

Mynd 1b. Kaplan-Meier-graf sem sýnir lifun án MACCE eftir kransæðahjáveitu a Íslandi 2001-2013 og 95\% öryggisbil (brotalínur).

á eftirfylgdartímanum. Heildartíðni kransæðavíkkunar eftir aðgerð var 7\% hjá báðum kynjum.

Í töflu IVb eru sýndir forspárpættir verri lifunar en peir voru hærri aldur, hjartabilun, langvinn nýrnabilun og sykursýki. Kvenkyn reyndist hins vegar ekki sjálfstæður forspárpáttur síðri lifunar (HR 1,10; 95\%-ÖB: 0,83-1,45, p=0,5).

\section{Umræður}

Pessi rannsókn náði til allra sjúklinga hjá heilli pjóð sem gengust undir kransæðahjáveitu á 13 ára tímabili. Ekki reyndist marktækur munur á horfum eftir kyni, hvort sem litið er til fylgikvilla, 30 daga dánartíðni eða lifunar. Petta eru mikilvægar upplýsingar fyrir pá sem koma að meðferð kransæðasjúkdóms hér á landi, en pó sérstaklega fyrir pau hundruð kvenna sem gengist hafa undir kransæðahjáveitu á peim rúmu premur áratugum sem pessar aðgerðir hafa verið framkvæmdar hérlendis. ${ }^{26}$

Hlutfall kvenna sem gengust undir kransæðahjáveitu á rannsóknartímabilinu var 18\% sem er heldur lægra en í erlendum rannsóknum par sem pað er yfirleitt á bilinu 22-30\%. ${ }^{8-12}$ Skýringin á pessu lága hlutfalli kvenna hérlendis liggur ekki fyrir en rannsókn á árangri kransæðavíkkana á Íslandi á árunum 1987-1998 sýndi einnig lágt hlutfall kvenna, sem pó jókst úr 19\% í 25\% allra víkkana á tímabilinu. ${ }^{27}$ Spurningin er hvort konum með alvarlegan kransæðasjúkdóm sé síður vísað í kransæðahjáveitu hér á landi. Í nýlegri rannsókn á rúmlega 100.000 sjúklingum sem fóru í kransæðamyndtöku vegna bráðs kransæðasjúkdóms í Svípjóð og

Tafla IVb. Sjálfstæðir forspárpættir verri lifunar eftir kransæðahjáveituaðgerð. Áhættuhlutfall og 95\%-öryggibil.

\begin{tabular}{lccc}
\hline Forspárpáttur & Áhættuhlutfall & $95 \%$ ÖB & p-gildi \\
\hline Aldur, ár & 1,08 & $1,06-1,10$ & $<0,001$ \\
\hline Kvenkyn & 1,10 & $0,83-1,45$ & 0,5 \\
\hline Háprýstingur & 0,91 & $0,70-1,17$ & 0,4 \\
\hline Sykursýki & 2,01 & $1,52-2,67$ & $<0,001$ \\
\hline Hjartabilun & 3,62 & $2,06-6,38$ & $<0,001$ \\
\hline Langvinn nýrnabilun & 1,74 & $1,33-2,30$ & $<0,001$ \\
\hline Fyrri saga um kransæðavíkkun & 1,20 & $0,91-1,64$ & 0,2 \\
\hline
\end{tabular}


á Íslandi á árunum 2007-2011 kom í ljós að konum með útbreiddan kransæðasjúkdóm var síður vísað í kransæðahjáveitu en körlum. ${ }^{28}$ Ennfremur sýndi pessi stóra rannsókn að konur með dreifðan kransæðasjúkdóm voru líklegri en karlar til að gangast undir kransæðavíkkun fremur en kransæðahjáveitu. Slíkt samrýmist ekki alpjóðlegum leiðbeiningum um meðferð kransæðasjúkdóms, enda eiga sömu ábendingar að gilda fyrir bæði kyn um kransæðavíkkun og hjáveituaðgerð. ${ }^{5}$ Niðurstöður okkar rannsóknar sýna pó að útbreiðsla kransæðasjúkdóms hjá peim sem gengust undir hjáveituaðgerð var sambærileg á milli kynja.

Hér á landi voru konur að jafnaði um fjórum árum eldri en karlar pegar pær gengust undir kransæðahjáveitu. Petta er í samræmi við erlendar rannsóknir, sem jafnframt hafa sýnt hærri tíðni sykursýki og blóðfituröskunar hjá konum. ${ }^{8,916}$ Slíkur munur á pessum áhættupáttum kransæðasjúkdóms kom ekki í ljós í okkar rannsókn, nema hvað háprýstingur reyndist algengari meðal kvenna og pær höfðu sjaldnar reykt, sem er sambærilegt við fyrrnefndar rannsóknir. Ekki kom á óvart að konur höfðu marktækt hærra EuroSCOREst fyrir aðgerð en karlar, eða 6,1 borið saman við 4,4 hjá körlum. Ef kvenkyni er sleppt í útreikingunum á EuroSCOREst var munurinn minni en engu að síður marktækur, eða 5,1 á móti 4,4 (p<0,001). Konur eru pví oftar í svokölluðum hááhættuhópi, sem er skilgreindur sem EuroSCOREst yfir $6 .{ }^{15}$

Tíðni minniháttar fylgikvilla, svo sem nýtilkomins gáttatifs, lungnabólgu og yfirborðssýkinga í skurðsári reyndist sambærileg milli kynja. Konur fengu oftar pvagfærasýkingu sem skýrist af pví að pessar sýkingar eru almennt algengari hjá konum. ${ }^{29}$ Ekki reyndist munur á tíðni alvarlegra fylgikvilla hjá kynjunum.

Einungis 12 konur (4\%) létust innan 30 daga frá aðgerð, sem er sambærilegt nýlegum erlendum rannsóknum. ${ }^{8-11}$ Í pessu sambandi er vert að hafa í huga að í okkar rannsókn voru teknar með allar hjáveituaðgerðir, par á meðal neyðaraðgerðir. Ef árangur valaðgerða er skoðaður sérstaklega reyndist 30 daga dánartíðni kvenna og karla sambærileg, eða aðeins 1,3\% og 1,4\%. Tíðni neyðaraðgerða var svipuð milli kynja og prátt fyrir að dánartíðni kvenna innan 30 daga eftir neyðarðagerð væri hlutfallslega hærri, eða 30\% samanborið við 19\% hjá körlum, reyndist sá munur ekki marktækur. Kvenkyn reyndist heldur ekki sjálfstæður forspárpáttur fyrir dauða innan 30 daga í pessari rannsókn. Rannsóknum erlendis hefur ekki öllum borið saman hvort kvenkyn sé sjálfstæður forspárpáttur dauða innan 30 daga. Flestar rannsóknir benda pó til pess, eins og safngreining Alam og félaga. ${ }^{16}$

Á eftirfylgdartímanum sem var langur, eða tæp 7 ár, reyndist tíðni endurhjáveitu mjög lág hjá báđum kynjum en einungis ein kona og 6 karlar purftu á slíkri aðgerð að halda. Tíðni kransæðavíkkana, með eða án stoðnets, var sömuleiðis lág, eða 8\% hjá báðum kynjum. Petta eru jákvæðar niðurstöður og benda til pess að árangur kransæðahjáveitu til lengri tíma sé mjög góður, og pað fyrir bæði kyn.

Kvenkyn reyndist hvorki sjálfstæður forspárpáttur dauða innan 30 daga frá aðgerð né spá fyrir um síðri lifun með Coxaðhvarfsgreiningu, ólíkt pví sem safngreining Alam og félaga frá 2013 sýndi. ${ }^{16}$ Ekki er ljóst af hverju okkar rannsókn ber ekki saman við flestar erlendu rannsóknanna, en tíðni sumra áhættupátta kransæðasjúkdóms eins og sykursýki er lægri hér en víða í Evrópu. ${ }^{30}$ Sykursýki reyndist sjálfstæður forspárpáttur síðri lifunar í pessari rannsókn. Vissulega er rannsóknarbýðið lítið miðað við margar erlendu rannsóknanna og pví ekki hægt að útiloka villu af gerð II við tölfræðiúrvinnslu. Pó hafa nokkrar erlendar rannsóknir komist að svipuðum niðurstöðum og okkar., ${ }^{8,14,31}$ Aðrar rannsóknir ${ }^{11,12}$ par á meðal ofangreind safngreining, ${ }^{16}$ hafa sýnt að kvenkyn er sjálfstæður forspárpáttur bæði fyrir dauða innan 30 daga frá aðgerð en einnig síðri lifun. Í rannsókn Guru og félaga var lifun sjúklinga sem gengust undir kransæðahjáveitu borin saman við lifun einstaklinga af sama aldri og kyni. Í ljós kom að lifun kvenna var síðri en karla eftir kransæðahjáveitu en í almennu pýði reyndist lifun kvenna hins vegar betri. ${ }^{12}$ Hér á landi er meðalævilengd kvenna í almennu pýði einnig meiri, eða 83,6 ár borið saman við 81 ár hjá körlum. ${ }^{32}$

Ýmsar kenningar hafa verið settar fram um pað af hverju konum farnast verr eftir kransæðahjáveitu. Konurnar eru eldri og hafa aukna sjúkdómabyrði, eins og hærri tíðni sykursýki, háprýstings og blóðfituröskunar., Раð að auki hafa rannsóknir sýnt að konum sé vísað í aðgerð við lengra genginn kransæðasjúkdóm og séu ólíklegri til að fara í valaðgerð.10,11 Er skýringin talin að hluta geta legið í pví að einkenni kvenna eru oft á tíðum frábrugðin einkennum karla. Auk pess eru kransæðar fíngerðari hjá konum, sem gerir aðgerðina tæknilega erfiðari og pað getur haft áhrif á endingu æðatenginga. ${ }^{33,34}$

Helsti styrkur pessarar rannsóknar er að hún tekur til allra sjúklinga sem gengust undir kransæðahjáveituaðgerð á einum spítala hjá heilli pjóð á 13 ára tímabili. Skráning á síðkomnum afdrifum sjúklinga var nákvæm en allar endurinnlagnir sjúklinganna voru skoðaðar, bæði á Landspítala og á sjúkrahúsum á landsbyggðinni. Auk pess fengust upplýsingar um dánardag allra sjúklinga frá Dánarmeinaskrá Landlæknisembættis. Veikleiki rannsóknarinnar er að hún er afturskyggn og upplýsingar um áhættupætti, sögu hjarta- og æðasjúkdóma og einkenni pví ekki eins nákvæmar og verið hefði í framsýnni rannsókn. Jafnframt voru einkenni sjúklinga ekki metin eftir aðgerð. Pá er rannsóknarpýðið minna en í flestum erlendum rannsóknum og taka parf tillit til pess við túlkun niðurstaðna.

Pessi rannsókn sýnir að árangur kransæðahjáveituaðgerða hér á landi er sambærilegur hjá konum og körlum. Tíðni snemm- og síðkominna fylgikvilla reyndist sambærileg milli kynja líkt og 30 daga dánartíðni. Lifun var einnig sambærileg fyrir bæði kyn, en 5 árum frá aðgerð eru $87 \%$ kvenna á lífi, sem verður að teljast góður árangur.

\section{Pakkir}

Pakkir fær Gunnhildur Jóhannsdóttir, skrifstofustjóri á skurðdeild Landspítala, fyrir aðstoð við leit að sjúkraskrám. Pessi rannsókn var styrkt af Vísindasjóði Landspítala, Rannsóknarsjóði Háskóla Íslands, Minningarsjóði Helgu Guðmundsdóttur og Sigurliða Kristjánssonar og einnig GoRed samtökunum á Íslandi. 
1. Aspelund T, Gudnason V, Magnusdottir BT, Andersen K, Sigurdsson G, Thorsson B, et al. Analysing the large decline in coronary heart disease mortality in the Icelandic population aged 25-74 between the years 1981 and 2006 PloS one 2010; 5: e13957.

2. Jousilahti P, Vartiainen E, Tuomilehto J, Puska P. Sex, age, cardiovascular risk factors, and coronary heart disease - A prospective follow-up study of 14.786 middle-aged men and women in Finland. Circulation 1999; 99: 1165-72.

3. Mendelsohn ME, Karas RH. The protective effects of estrogen on the cardiovascular system. N Engl J Med 1999; 340: 1801-11

4. Canto JG, Rogers WJ, Goldberg RJ, Peterson ED, Wenger NK, Vaccarino V, et al. Association of Age and Sex With Myocardial Infarction Symptom Presentation and In-Hospital Mortality. JAMA 2012; 307: 813-22.

5. Windecker S, Kolh P, Alfonso F, Collet JP, Cremer J, Falk V, et al. 2014 ESC/EACTS guidelines on myocardial revascularization. EuroIntervention 2015; 10: 1024-94.

6. Ibanez B, James S, Agewall S, Antunes MJ, BucciarelliDucci C, Bueno H, et al. 2017 ESC Guidelines for the management of acute myocardial infarction in patient presenting with ST-segment elevation. Rev Esp Cardiol (Engl Ed) 2017; 70: 1082

7. Alabas OA, Gale CP, Hall M, Rutherford MJ, Szumme K, Lawesson SS, et al. Sex Differences in Treatments, Relative Survival, and Excess Mortality Following Acute Myocardial Infarction: National Cohort Study Using the SWEDEHEART Registry. J Am Heart Ass 2017; 6: e007123

8. Saxena A, Dinh D, Smith JA, Shardey G, Reid CM Newcomb AE. Sex differences in outcomes following isolated coronary artery bypass graft surgery in Australian patients: analysis of the Australasian Society of Cardiac and Thoracic Surgeons cardiac surgery database. Eur Cardio-Thorac Surg 2012; 41: 755-62.

9. Aldea GS, Gaudiani JM, Shapira OM, Jacobs AK, Weinberg $\mathrm{J}$, Cupples AL, et al. Effect of gender on postoperative outcomes and hospital stays after coronary artery bypass grafting. Ann Thorac Surg 1999; 67: 1097-103.

10. Bukkapatnam RN, Yeo KK, Li Z, Amsterdam EA Operative Mortality in Women and Men Undergoing Coronary Artery Bypass Grafting (from the California Coronary Artery Bypass Grafting Outcomes Reporting Program). Am J Cardiol 2010; 105: 339-42.

11. Alam M, Lee V-V, Elayda MA, Shahzad SA, Yang EY, Nambi $V$, et al. Association of gender with morbidity and mortality after isolated coronary artery bypass grafting. A propensity score matched analysis. Int J Cardiol 2013; 167: 180-4.
12. Guru V, Fremes SE, Tu JV. Time-related mortality for women after coronary artery bypass graft surgery: a population-based study. J Thorac Cardiovasc Surg 2004; 127: 1158-65.

13. Humphries KH, Gao M, Pu A, Lichtenstein S, Thompson CR. Significant improvement in short-term mortality in women undergoing coronary artery bypass surgery (1991 to 2004). J Am Coll Cardiol 2007; 49: 1552-8.

14. Abramov D, Tamariz MG, Sever JY, Christakis GT Bhatnagar G, Heenan AL, et al. The influence of gender on the outcome of coronary artery bypass surgery. Ann Thorac Surg 2000; 70: 800-5.

15. Nashef SAM, Rogues F, Michel P, Gauducheau E Lemeshow S, Salamon R, et al. European system for cardiac operative risk evaluation (EuroSCORE). Eur J CardioThorac Surg 1999; 16: 9-13.

16. Alam M, Bandeali SJ, Kayani WT, Ahmad W, Shahzad $\mathrm{SA}$, Jneid $\mathrm{H}$, et al. Comparison by Meta-Analysis of Mortality After Isolated Coronary Artery Bypass Grafting in Women Versus Men. Am J Cardiol 2013; 112: 309-17.

17. Toumpoulis IK, Anagnostopoulos CE, Balaram SK Rokkas CK, Swistel DG, Ashton RC, Jr., et al. Assessment of independent predictors for long-term mortality between women and men after coronary artery bypass grafting: are women different from men? J Thorac ass grafting: are women different

18. Oddsson SJ, Sigurjónsson H, Helgadóttir S, Sigurðsson MI, Viktorsson SA, Arnórsson T, et al. Tengsl offitu viō árangur kransæðahjáveituaðgerða. Læknablaðið, 2011; 97: 223-8.

19. Aðalsteinsson JA, Axelsson TA, Helgason D, Árnadóttir LÓ, Jóhannesdóttir H, Geirsson A, et al. Snemmkominn árangur kransæðahjáveituaðgerða hjá sjúklingum með sykursýki. Læknablaðið, 2014; 100: 507-12.

20. Árnadóttir LÓ, Axelsson TA, Helgason D, Jóhannesdótti H, Ađalsteinsson JA, Geirsson A, et al. Árangur kransæðahjáveituaðgerða hjá sjúklingum 50 ára og yngri. Læknablaðið, 2014; 100: 651-6.

21. Johannesdottir $\mathrm{H}$, Arnadottir LO, Adalsteinsson JA Axelsson TA, Sigurdsson MI, Helgadottir S, et al. Favourable long-term outcome after coronary artery bypass grafting in a nationwide cohort. Scand Cardiovasc J 2017; 51: 327-33

22. Association NYH, Harvey RM. Nomenclature and Criteria for Diagnosis of Diseases of the Heart and Great Vessels. Little, Brown and Company 1973.

23. Campeau L. Grading of angina-pectoris. Circulation 1976 54: 522-3.
24. National Kidney Foundation. KDOQI Clinical Practice Guideline for Diabetes and CKD: 2012 Update. Am J Kidney Diseases 2012; 60: 850-86.

25. Bellomo R, Ronco C, Kellum JA, Mehta RL, Palevsky P, Acute Dialysis Quality Initiative Workgroup. Acute renal failure - definition, outcome measures, animal models, fluid therapy and information technology needs: the Second International Consensus Conference of the Acute Dialysis Quality Initiative (ADQI) Group. Crit Care 2004; 8: R204-R12.

26. Sigurjónsson $\mathrm{H}$, Helgadóttir S, Oddsson SJ, Sigurðsson MI, Geirsson A, Arnórsson T, et al. Árangur kransæðahjáveituaðgerða á Íslandi 2002-2006. Læknablaðið 2012; 98: 451-6.

27. Danielsen R, Eyjólfsson $K$, Sigurðsson AF, Jónmundsson EH. Árangur kransæðavíkkunaraðgerđa á Íslandi 19871998. Læknablaðið 2000; 86: 241-9.

28. Gudnadottir GS, Andersen K, Thrainsdottir IS, James SK, Lagerqvist B, Gudnason T. Gender differences in coronary angiography, subsequent interventions, and outcomes among patients with acute coronary syndromes. Am Heart J 2017; 191: 65-74.

29. Sedor J, Mulholland SG. Hospital-acquired urinary tract infections associated with the indwelling catheter. Urol Clin North Am 1999; 26: 821-8.

30. Bergsveinsson J, Aspelund T, Guðnason V, Benediktsson R. Algengi sykursýki af tegund tvö á Íslandi 1967-2002. Læknablaðið 2007; 93: 397-402.

31. Nicolini F, Vezzani A, Fortuna D, Contini GA, Pacini D, Gabbieri D, et al. Gender differences in outcomes following isolated coronary artery bypass grafting: long-term results. J Cardiothorac Surg 2016; 11: 144.

32. Hagstofa Íslands. Konur og karlar á Íslandi 2017. hagstofa. is - febrúar 2018.

33. Duvernoy CS, Smith DE, Manohar P, Schaefer A, KlineRogers E, Share D, et al. Gender differences in adverse outcomes after contemporary percutaneous coronary intervention: an analysis from the Blue Cross Blue Shield of Michigan Cardiovascular Consortium (BMC2) percutaneous coronary intervention registry. Am Heart J 2010; 159: 677-83

34. Cantor WJ, Miller JM, Hellkamp AS, Kramer JM, Peterson $\mathrm{ED}$, Hasselblad V, et al. Role of target vessel size and body surface area on outcomes after percutaneous coronary interventions in women. Am Heart J 2002;144: 297-302.

Barst til blaðsins 2. apríl 2018, sampykkt til birtingar 25. júní 2018.

\section{ENGLISH SUMMARY}

\section{Outcome of coronary artery bypass grafting in women in Iceland}

\author{
Helga Rún Garðarsdóttir ${ }^{1}$ \\ Linda Ósk Árnadóttir ${ }^{1}$ \\ Jónas A. Aðalsteinsson ${ }^{1}$ \\ Hera Jóhannesdóttir ${ }^{1}$ \\ Sólveig Helgadóttir ${ }^{4}$ \\ Pórdís Jóna Hrafnkelsdóttir ${ }^{2,3}$ \\ Arnar Geirsson ${ }^{5}$ \\ Tómas Guðbjartsson ${ }^{1,3}$
}

\section{Introduction}

The aim of this study was to evaluate the outcome of coronary artery bypass grafting (CABG) in women compared to men, with focus on short-term and long-term complications, 30 day mortality and survival.

\section{Materials and methods}

This was a retrospective study on all CABG patients operated in Iceland between 2001 and 2013. Clinical information was gathered from hospital charts and survival data was obtained from the National Statistics in Iceland. Overall survival was estimated with the Kaplan- Meier method. Logistic and Cox regression analysis were used to identify predictors of operative mortality and long-term survival. Mean follow-up was 6.8 years.

\section{Results}

Of 1755 patients 318 were women (18\%). Women were on average four years older than men at the time of operation (69 vs. $65 \mathrm{yrs}, p<0.001$ ). Female patients had a higher incidence of hypertension (72 vs. $64 \%, p=0.009$ ) and their EuroSCOREst was higher (6.1 vs. $4.3, p<0.001$ ). The prevalence of diabetes, dyslipidemia and the extent of coronary artery disease was comparable between groups. The rate of short-term complications, both minor (53\% vs. $48 \%$, $p=0.07)$ and major ( $27 \%$ vs. $32 \%, p=0.2)$, was similar and operative mortality for women was not statistically different from males ( $4 \%$ vs. $2 \%$ $p=0.08)$. Female gender was neither found to be a predictor of 30 -day mortality (OR $0.99 ; 95 \%-\mathrm{Cl}$ : 0.98-1.01) nor survival (HR 1,08; 95\%-ÖB: 0,82$1,42)$.

\section{Conclusions}

The number of women that undergo CABG is low and they are four years older than men when operated on. As is the case with men, outcome following CABG in Iceland is very good for women, their overall five-year survival being $87 \%$. 